\title{
Connessioni il disegno della casa a pianta quadrata dal Rinascimento alla contemporaneità
}

Paolo Giordano

Abstract

II disegno della bellezza espresso dall'opera di Andrea Palladio rappresenta la sintesi più alta della cultura figurativa rinascimentale proprio per quella capacità riassuntiva maturata in seguito allo studio dei precetti vitruviani nonché a quello delle riflessioni grafiche e teoriche presenti nei trattati degli architetti e degli intellettuali quattrocenteschi e cinquecenteschi come Leon Battista Alberti, Alvise Cornaro e Daniele Barbaro.

II modello iconografico della villa palladiana rappresenta il migliore emblema architettonico per illustrare le tappe di una complessa avventura delle idee, fatta di connessioni concettuali e grafiche, avente come tema la casa ideale dell'uomo. II tema della casa residenziale basata su una pianta quadrata è un tema talmente ricorrente nella cultura architettonica europea che anche la disciplina progettuale contemporanea, come la recente elaborazione architettonica della Rotonda House di Alberto Campo Baeza a Madrid dimostra, conferma il tema delle 'connessioni' teoriche e realizzative quale modalità ricorrente del fare nell'architettura.

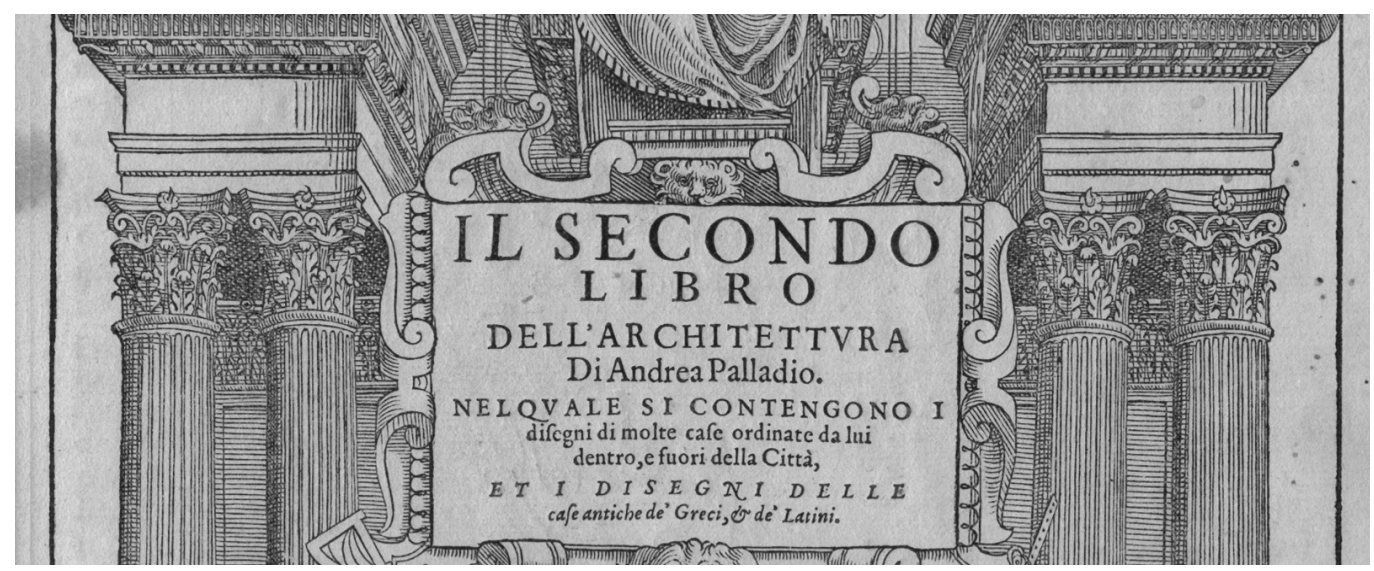




\section{Imitazioni del modello palladiano: le varianti seicentesche della villa all'italiana}

Il disegno della bellezza espresso dall'opera di Andrea Palladio, esteso oltre che al suo contributo di eccelso disegnatore anche a quello di superbo trattatista, rappresenta la sintesi più alta della cultura figurativa rinascimentale proprio per quella capacità riassuntiva maturata in seguito allo studio dei precetti vitruviani nonché a quello delle riflessioni grafiche e teoriche presenti nei trattati degli architetti e degli intellettuali quattrocenteschi e cinquecenteschi come Leon Battista Alberti, Alvise Cornaro e Daniele Barbaro. Nello specifico, il progetto de La Rotonda (fig. I) segna una netta linea di demarcazione tra un prima e un dopo all'interno della cultura architettonica europea attraverso la continua rielaborazione, tra Seicento ed Ottocento, di imitazioni e connessioni tipologiche e formali più o meno riuscite. In tal senso, il modello iconografico della villa palladiana rappresenta il migliore emblema architettonico per illustrare, in generale, i tratti salienti di un fondamentale snodo concettuale nella storia dell'architettura europea e, in particolare, le tappe di una complessa arventura delle idee, fatta di connessioni concettuali e grafiche, avente come tema la casa ideale dell'uomo. II tema della casa residenziale basata su una pianta quadrata è un tema talmente ricorrente nella cultura architettonica europea che anche la disciplina progettuale contemporanea, come la recente elaborazione architettonica della Rotonda House di Alberto Campo Baeza a Madrid dimostra, conferma il tema delle 'connessioni' teoriche e realizzative quale modalità ricorrente del fare nell'architettura. In tale prospettiva, la Rotonda di Andrea Palladio rappresenta l'ultimo oggetto architettonico della cultura umanistica rinascimentale nonché il primo modello tipologico di villa extraurbana da esportazione se riferito a quel cosiddetto manierismo ripropositivo che interesserà il territorio europeo, a partire dall'opera di Vincenzo Scamozzi, nei quattro secoli successivi. Come sottolinea Howard Burns, "La più feconda merce d'esportazione nei paesi d'Oltralpe fu trasportata ed assimilata facilmente; I Quattro Libri dell'Architettura (1570) di Andrea Palladio, in cui il grande architetto audacemente dichiara di aver messo a disposizione le proprie opere perché, a fronte delle carenze

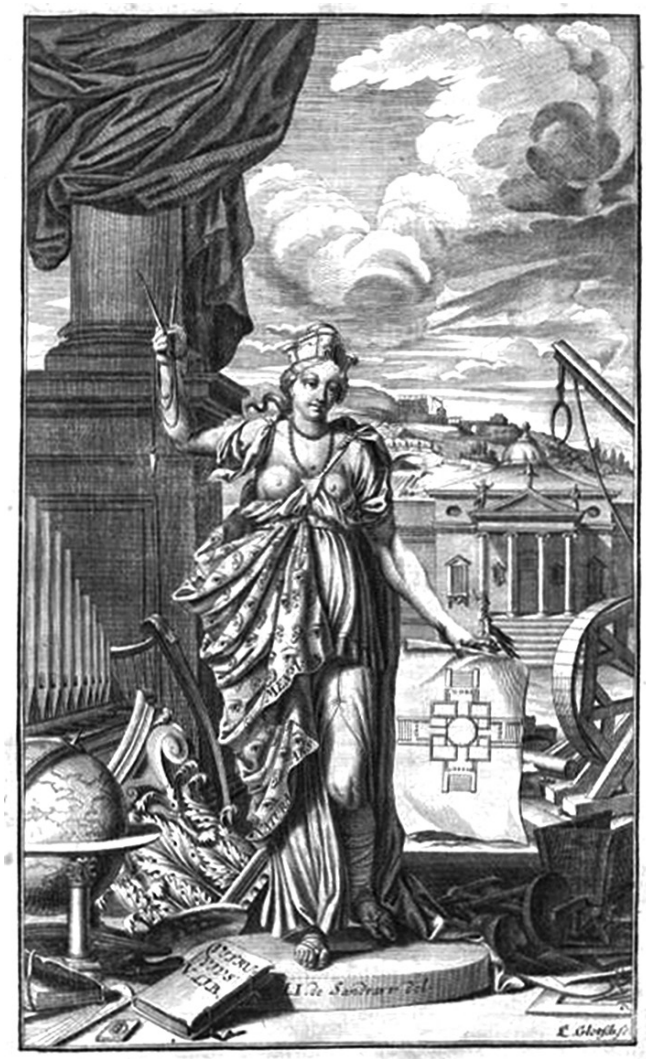


delle antiche case di campagna, esse siano d'esempio. II libro di Palladio ebbe una certa influenza sulla progettazione di residenze di campagna più piccole in Francia, ma soprattutto in Inghilterra, grazie alla conoscenza diretta della sua opera da parte dell'architetto reale Inigo Jones: lo stesso Jones possedeva la maggior parte dei disegni di Palladio rimasti, che successivamente passarono da un architetto all'altro finchè, nel I720-I721, non furono acquistati da Lord Burlington, regista principale del revival palladiano del $X V I I$ secolo e il più creativo degli architetti palladiani inglesi dopo Jones" [Burns 20 I2, p. I I].

E' noto che il modello architettonico della bellezza ideale rappresentato dalla Rotonda ha ispirato il lavoro di molti architetti anche fuori dalla penisola italiana: oltre che in Francia con il lavoro dei vari Antonie Le Pautre, Germani Boffrand, e Jean Nicolas Luis Durand - ed in Germania - con i progetti di Paul Deker, Christian Cay Lorenz - sarà proprio in Inghilterra che si svilupperà, in generale, il maggior tributo progettuale all'architettura palladiana e, in particolare, alla bellezza di Villa Capra attraverso la realizzazione di molteplici ville residenziali, tra le quali emerge, per magnificenza, la Chiswick House: un ampliamento di una vecchia dimora nobile disegnato da Lord Richard Boyle, terzo conte di Burlington nelle campagne del Middlesex.

\section{La raffigurazione anglosassone del bello: importazione e sviluppo del modello palladiano}

Se l'opera di Lord Burlington è ascrivibile al neopalladianesimo, maturato in Inghilterra nel diciottesimo secolo, l'originario palladianesimo britannico ha il suo capostipite nella figura di Inigo Jones, architetto londinese che, importando l'architettura rinascimentale italiana oltre il canale della Manica a partire dagli inizi del diciassettesimo secolo, si pone come unico e vero nume tutelare dell'estetica rinascimentale d'impronta razionale. Tutto questo mentre in Italia, dopo la prima deriva manierista cinquecentesca, si sviluppa la drammatizzazione linguistica insita nel barocco seicentesco attraverso le figure di Francesco Borromini e Gian

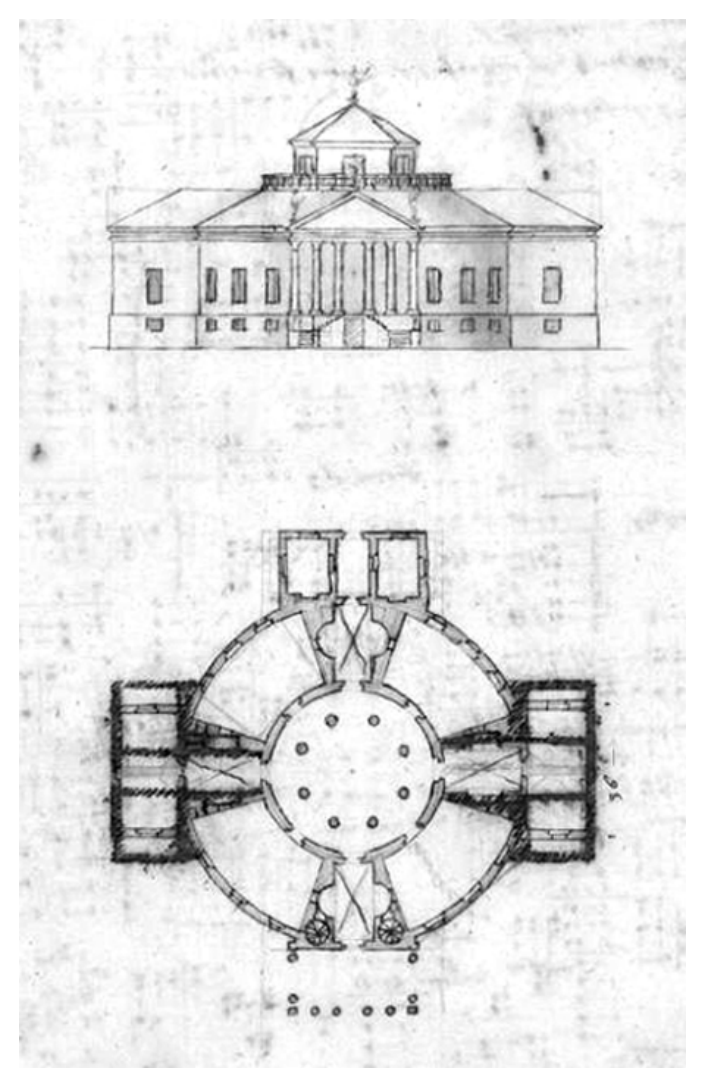


Lorenzo Bernini colpevoli, secondo Colen Campbell, autore del Vitruvius Britannicus, di aver tradito l'ideale semplicità dell'Antichità in favore di capricciosi ornamenti e incomprensibili formalismi concavo-convessi.

La venustas perseguita da Inigo Jones è basata su di una interpretazione razionale e matematica capace, come ricordava RudolfWittkower "di conferire ai suoi edifici quel carattere globale di lucidità, equilibrio e armonia" [Wittkower 1984, p. 92]. Un carattere che s'irrigidirà nelle successive ricerche dei suoi allievi come, ad esempio, nell'opera di John Webb che rappresenta, di fatto, l'inizio di quel neopalladianesimo consacrato all'imitazione della Rotonda, avviato verso la fine del diciassettesimo secolo, che sfocierà, nel diciottesimo e diciannovesimo secolo, sia nel lavoro di Lord Burlington e della sua cerchia di architetti, sia nell'opera nord-americana di Thomas Jefferson. Al di là dell'interesse per l'opera complessiva di Andrea Palladio, l'exemplum architettonico di riferimento degli architetti neopalladiani britannici resta, infatti, Villa Capra, reinterpretata assiduamente sia dal punto di vista tipologico e sia da quello morfologico: la Single-storey House di John Webb (fig. 2), pur configurandosi come un'esercitazione grafica, rappresenta il primo tentativo della lunga serie di emulazioni architettoniche aventi come oggetto il modello di bellezza universale progettato dall'architetto padovano. Contemporaneamente, in Francia, secondo modalità ben più monumentali, la sperimentazione progettuale d'impronta palladiana si sviluppa attraverso il contributo di German Boffrand con il progetto di un "padiglione delle delizie" inserito nel parco di un castello. Nei disegni di Boffrand per il Padiglione del castello di Bouchefort la connessione alla Rotonda di Andrea Palladio è riferibile maggiormente all'aspetto morfologico piuttosto che a quello tipologico: si tratta, in buona sostanza, un esercizio progettuale che aspira ad una magnificenza estetica del tutto sovradimensionata rispetto al modello di riferimento. II progetto di Germani Boffrand,così come in quello del suo connazionale Antonie Le Pautre per la Maison de Plaisance, similmente alla successiva sperimentazione di Herman Korb e Paul Decker (fig. 3) in Germania, non riescono a sviluppare un'affinità elettiva, di carattere progettuale e concettuale, con la Rotonda di Andrea Palladio in virtù di un mancato retro-

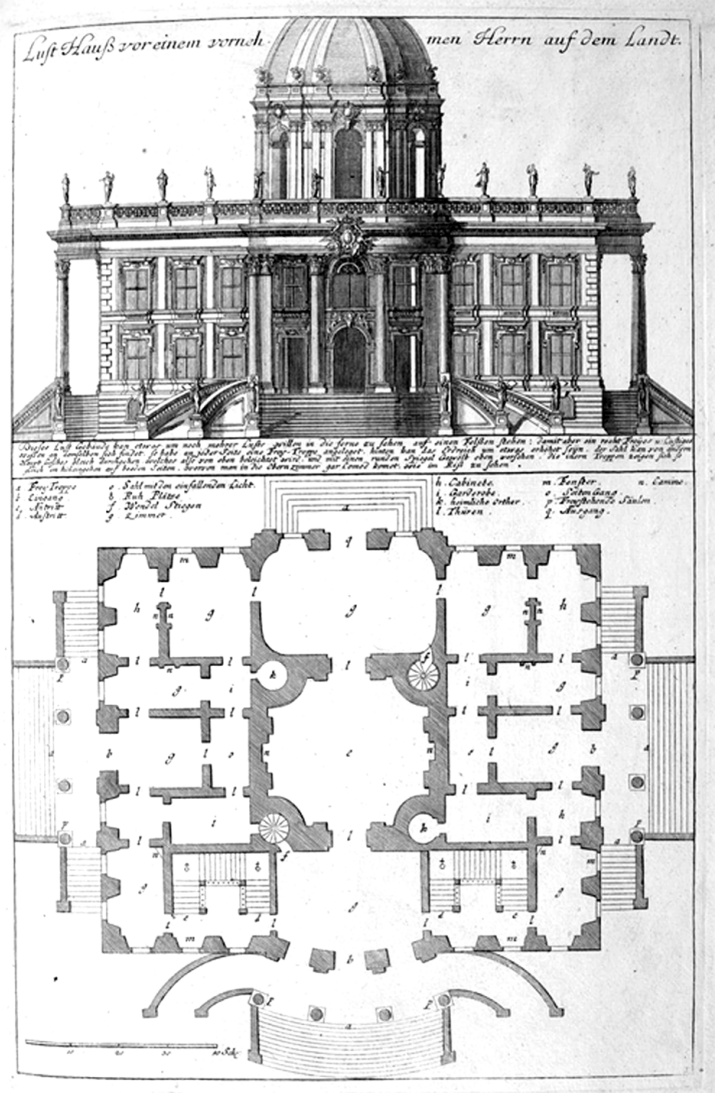


terra culturale capace di alimentare nei paesi di origine un virtuoso dibattito tra architetti, artisti, critici ed intellettuali. Viceversa, in Inghilterra, sulla base dell'impegno intellettuale e progettuale di Inigo Jones, si svilupperà il cosiddetto 'english palladianism': una tendenza culturale e sociale esplosa non solo grazie al contributo del maestro seicentesco dell'architettura razionale inglese ma anche e soprattutto in virtù dell'opera teorica di un raffinato intellettuale britannico e di quella pubblicistica di un astuto architetto veneziano ovvero Colen Campbell e Giacomo Leoni autori, il primo, del Vitruvius britannicus e, il secondo, del The architecture of Palladio: in four books. Due pubblicazioni, editate tra il 1715 ed il 1720, che fungeranno da testi propulsori a quell'emergente gusto neopalladiano meglio conosciuto come Palladian Taste. Un gusto che si concretizza nell'opera di Colin Campbell realizzata nelle campagne del Kent, tra il 1722 ed il 1724, (fig. 4) ovvero il Mereworth Castle. Un'opera architettonica che si distanzia poco dal suo modello architettonico originale, come sottolineato dallo stesso progettista, attraverso differenze minime visibili sia all'esterno che all'interno dove la generosa estensione della superficie coperta consente il dispiegamento di una maggiore varietà di forme e misura nel disegno delle camere. Una differenziazione tipologica riscontrabile soprattutto nel disegno circolare, anziché triangolare, dei vani e delle rampe di scale ubicate attorno allo spazio principale, a doppia altezza, del salone centrale che risulta maggiormente illuminato, da un oculo aprentesi sulla cupola, in una variante di
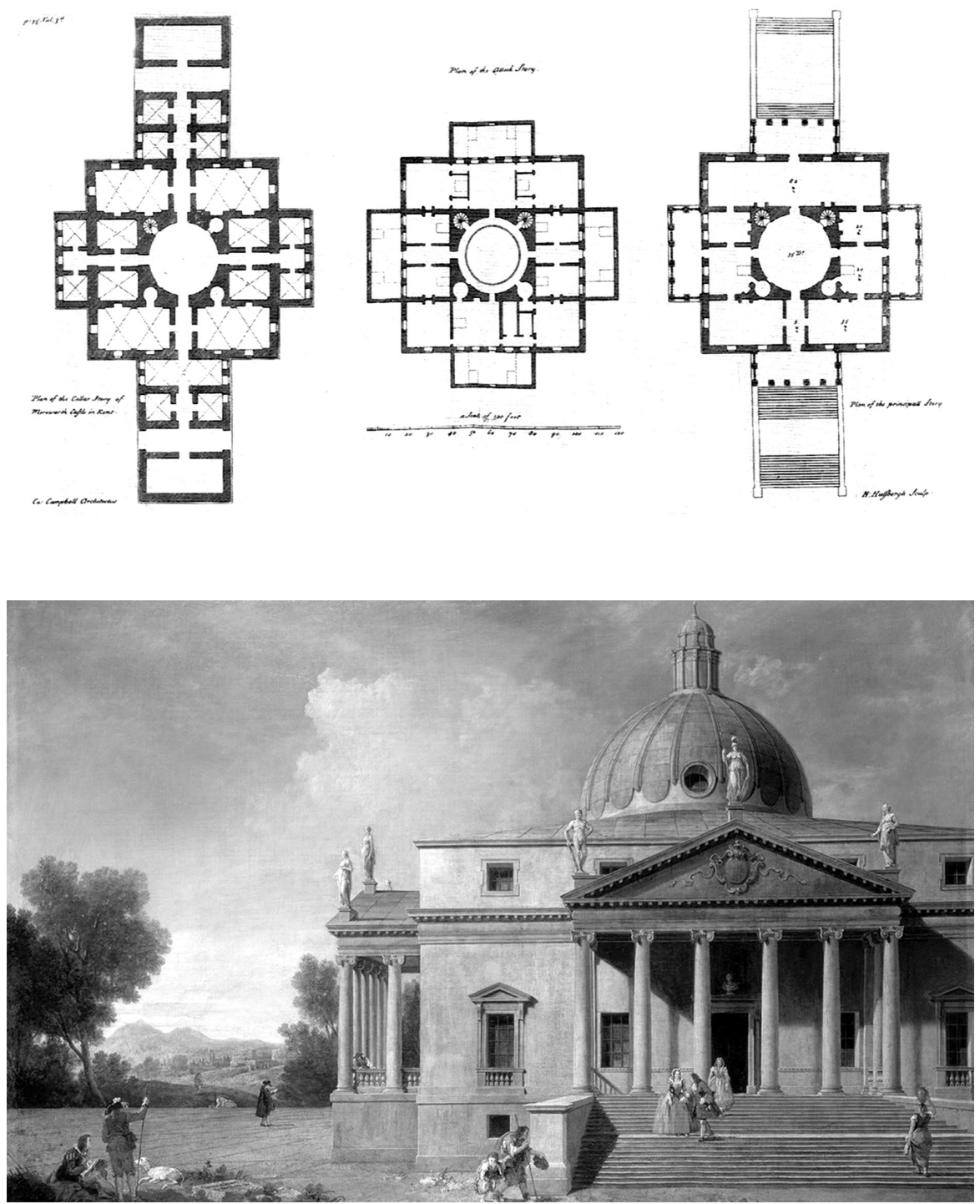
Fig. 6. Richard Boyle (Lord Burlington), alzato della facciata principale di

Chiswick House a Londra Londra, Library Drawings and Archives Collection, RIBA
Fig. 7.Thomas Jefferson, disegno per il concorso per la Casa del Presidente. National Archives of Maryland State, k. 126

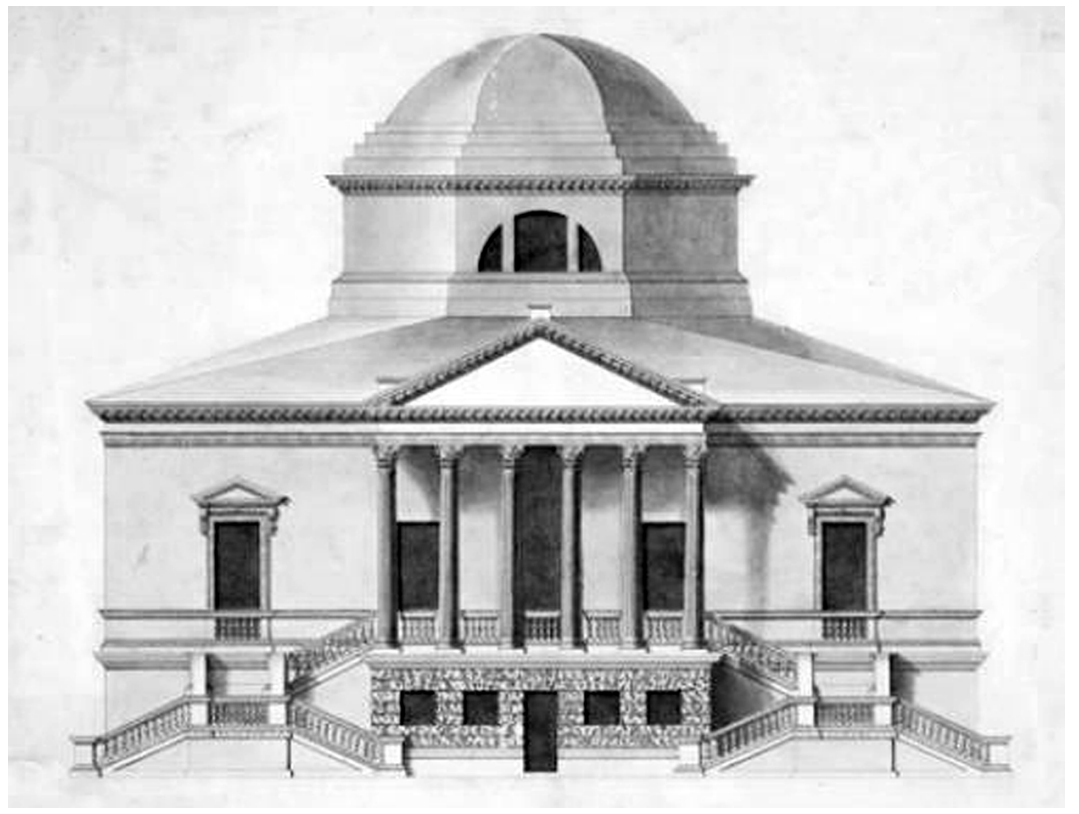

progetto dipinta anche da Antonio Vicentini e Francesco Zuccarelli (fig. 5). Un anno dopo la realizzazione di Colen Campbell segue, nel I725, l'omaggio di Lord Burlington alla Rotonda. Si tratta, nello specifico, di un ossequio architettonico filtrato, apparentemente, tramite la lezione di Inigo Jones, suo connazionale nonché antecedente estimatore di Andrea Palladio: la Chiswick House, ubicata in un fitto parco vegetazionale (fig. 6), rappresenta il principale esempio del neo-palladianesimo britannico che, attraverso le sculture del maestro vicentino e di quello londinese d'adozione collocate sulle estremità basamentali dell'edificio, dichiara apertamente le due principali fonti d'ispirazione e, in rapporto ad esse, l'autoreferenziale affinità elettiva.

La Chiswick House è la rappresentazione di un neo-palladianesimo imperfetto, ovvero di uno stile basato sulla riproposizione di elementi linguistici tratti sia dagli insegnamenti dell'antichità, attraverso la rilettura diVitruvio, e sia dalle soluzioni architettoniche ereditate dalle testimonianze grafiche rinascimentali e post-rinascimentali di Palladio, Scamozzi e Inigo Jones. La Chiswick House rappresenta un pallido tentativo di riproposizione architettonica della perfezione palladiana che non giustifica la definizione ricorrente della casa nel Middlesex quale "manifesto of a Palladian perfection" [Pistis 20 I I, p. 43].

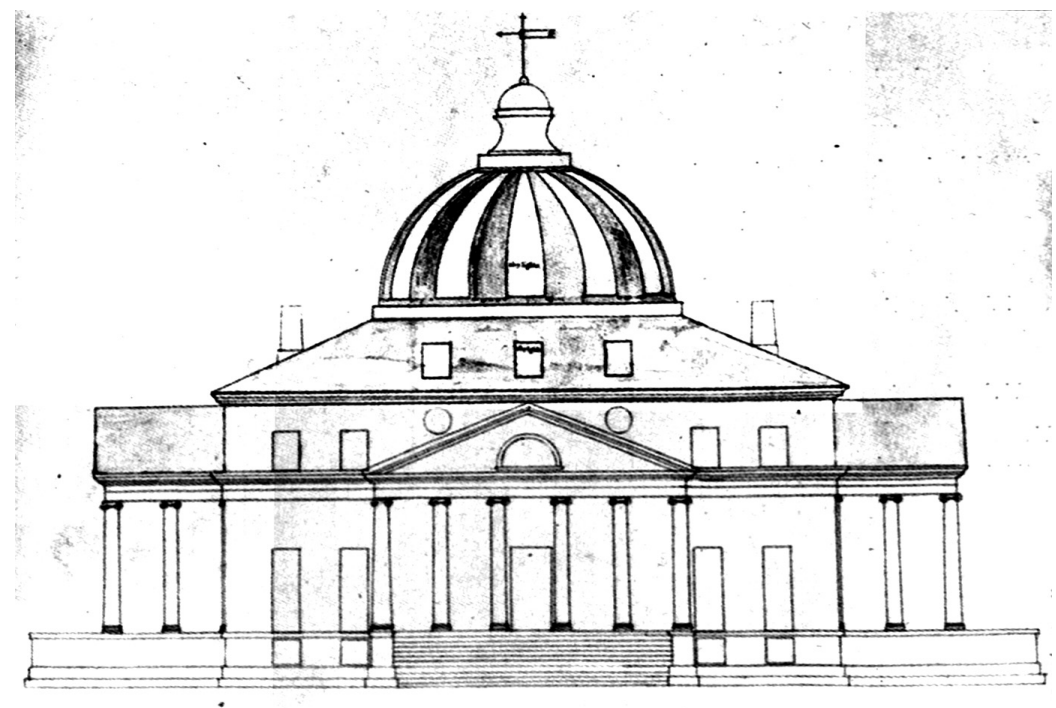


Fig. 8. Giacomo Leoni, alzato di villa Almerico Capra detta La Rotonda ridisegno, 1716, Londra, Library Drawings and Archives Collection, RIBA.
Contemporaneamente in Francia, attraverso l'opera progettuale di Gabriel-Pierre-Martin Dumont, si realizza un'ulteriore declassamento morfologico dell'opera originaria pur attraverso una sostanziale conferma di ordine tipologico: il disegno per un "belvedere che gli italiani chiamano casino" propone, infatti, l'eliminazione della classica cupola semisferica optando per una contraddittoria copertura quadrangolare a falde inclinate impostata su un salone centrale a doppia altezza, comunque ancora, a pianta circolare. Per ritrovare un nuovo inno alla bellezza, coerente con i presupposti palladiani, è necessario spostare l'attenzione sulla coeva produzione architettonica nord-americana.

II progetto del 1769 diThomas Jefferson per la casa di Monticello a Charlottesville e, successivamente, il concorso per la Casa del Presidente (fig. 7) nello Stato del Maryland, del I 792 rappresentano una vera rinascita della venustas palladiana in un ambito geografico nuovo rispetto a quello del vecchio continente europeo. Prerogativa, quest'ultima, rintracciabile nel disegno raffigurante il prospetto per la Casa del Presidente. Un disegno non molto dissimile dall'incisione illustrante la facciata di Villa Rotonda a Vicenza presente all'interno della traduzione inglese dei I Quattro libri dell'Architettura curata da Giacomo Leoni (fig. 8) e posseduta, insieme al Rules for Drawing the several Parts of Architecture pubblicato da James Gibbs nel 1732, dallo stesso Thomas Jefferson [Forster 1984, p. 398].

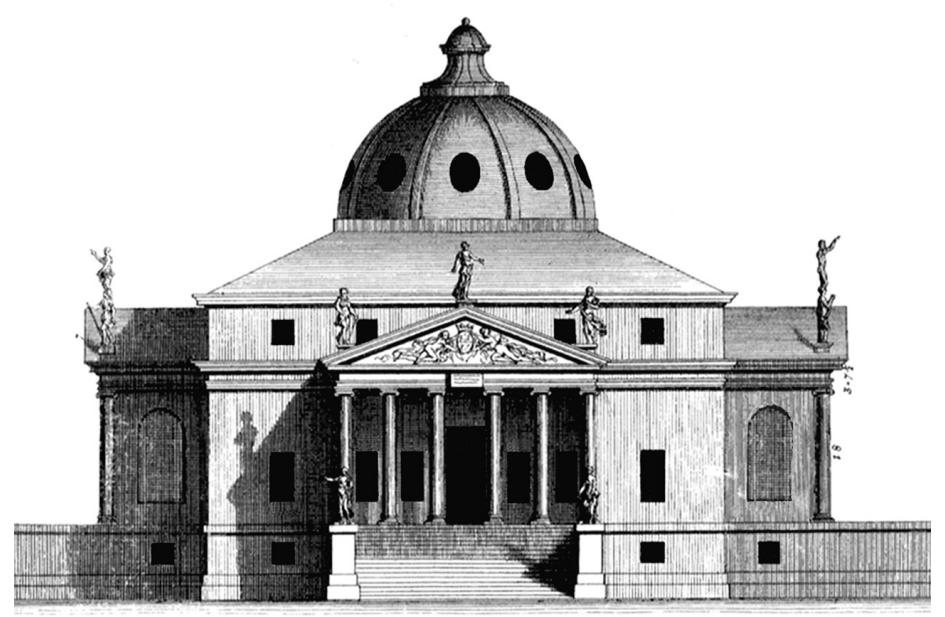

\section{La diffusione europea del modello palladiano tra Settecento e Ottocento: Germania e Francia}

L'illuminismo utilitaristico della seconda metà del Settecento impedirà all'ideale palladiano di svilupparsi e proliferare in Europa così come il neo-palladianesimo imperfetto di matrice anglosassone era riuscito a fare nel corso del diciassettesimo e diciottesimo secolo nei territori extraurbani dell'isola britannica. Diverse tipologie residenziali a schema centrale saranno progettate e realizzate tentando, invano, di raggiungere quell'ideale bellezza detenuta dal modello palladiano. Molti pastiches architettonici riaffermeranno attraverso l'imperfezione delle proprie caratteristiche tipo-morfologiche e linguistiche la lontananza dalla bellezza espressa da Villa Capra. È il caso, ad esempio, della Villa nel giardino di Christian Cay Lorenz o della neo-decò casa di campagna di Wilhelm Gottlieb Becker nonché quella di Mathias Fortunat Koller: edifici monoresidenziali accomunati da forti tensioni emulative, pari solo alla loro ampollosa mancanza di sobrietà architettonica, nei confronti della Rotonda palladiana. Solo tra la fine del diciottesimo e gli inizi del diciannovesimo secolo - attraverso il progetto della Maison a neuf (fig. 9) di Jean Nicolas-Louis Durand - si potranno ammirare degli esercizi progettuali capaci di restituire, fuori dalla tentazione della riproposizione mimetica del modello originario, quel senso di dignità architettonica al tentativo di ragionare sull'insegnamento della perfezione architettonica, quindi della bellezza, emanata dalla Rotonda di Andrea Palladio. 
Fig. 9. Jean Nicolas-Louis Durand, pianta, alzati, sezioni, della Maison a neuf cases, da Précis des lecons d'architecture Paris $1802-1805$

primiere partie, $\mathrm{PI} .2$

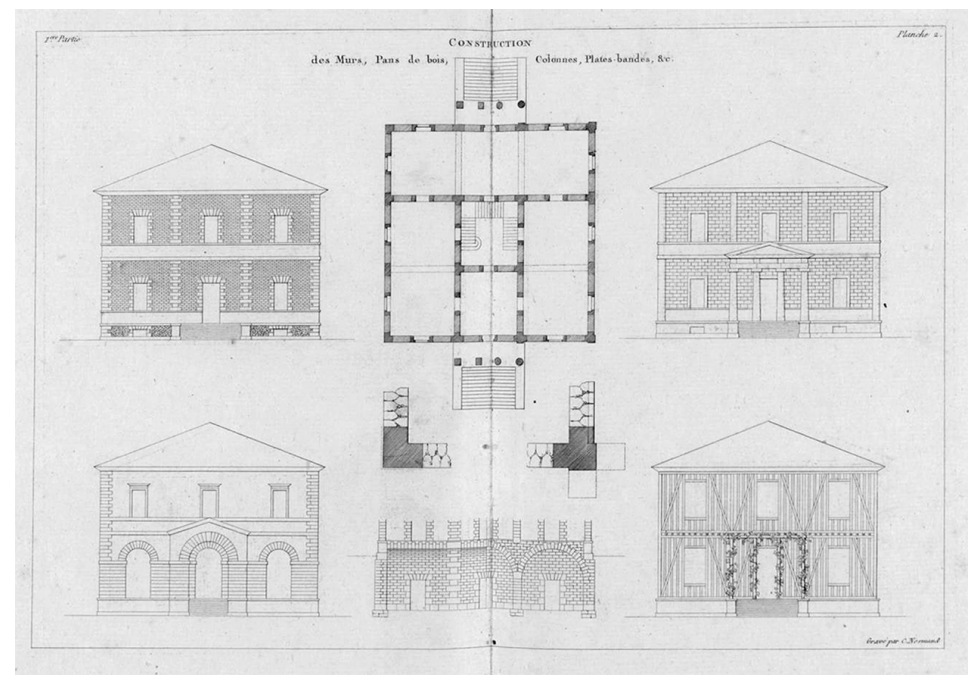

La sobrietà rintracciabile nel progetto di Jean Nicolas-Louis Durand per la Maison a neuf cases, pubblicata nel suo Precis des leçons d'architecture a Parigi nel I802, è la miglior affermazione delle possibili connessioni teoriche e progettuali che l'architettura può sostenere in riferimento ad una precisa idea, archetipale, contenuta in un modello universale come risulta essere la Rotonda di Andrea Palladio. Un modello che, grazie alle connessioni teorico grafiche, è in grado di offrire risposte anche alla nostra contemporaneità cosi come risulta evidente dalle riflessioni di Alberto Campo Baeza per la sua recente opera intitolata Rotonda House (fig. 10): "Costruire una casa in cima a una collina, come lo stesso Palladio, è il sogno di ogni architetto. Stiamo progettando di costruire una casa nella periferia di Madrid, in un luogo che, nonostante l'architettura circostante, ha una certa somiglianza con la posizione di alcune delle ville di Palladio. E stiamo cercando di imparare qualche lezione dal maestro. In cima a una collina dove la vista è più bella più si sale in alto. E quando raggiungiamo il punto più alto consentito dal regolamento, quei panorami sono straordinari: la sierra di Madrid, il Guadarrama, e il cornicione occidentale della città con le sue quattro torri. Proponiamo una pianta quadrata di $12 \times 12 \mathrm{~m}$, divisa in nove quadranti uguali di $4 \times 4 \mathrm{~m}$. Una pianta molto flessibile dove tutto è possibile. Le aree funzionali sono situate nei punti più convenienti, alla maniera palladiana [...] Quando Mies van der Rohe visiterà la casa, manderà un WhatsApp al suo amico Palladio per fargli visita. E Palladio gli risponderà che avrebbe voluto avere i mezzi per farlo così: Mies dirà che un po' di questo gli passava per la testa quando ha progettato la sua casa 50×50" [Campo Baeza 2000].

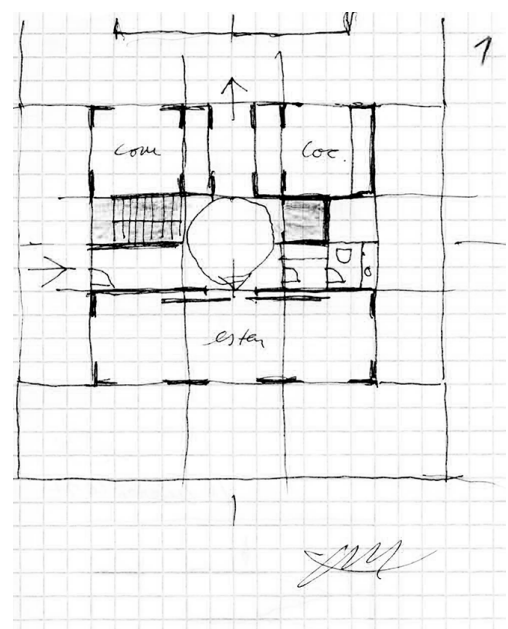




\section{Riferimenti bibliografici}

Burns Howard (2012). La villa italiana del Rinascimento. Costabbisara (VI): Angelo Colla Editore.

Chiodo Simona (20 I I). Estetica dell'Architettura. Roma: Carocci Editore.

De Fusco Renato (2004). II codice di architettura. Antologia di Trattatisti. Napoli: Liguori editore.

Geymonat Ludovico (1997). Storia del pensiero filosofico e scientifico. Milano: Garzanti.

Giordano Paolo (20I5). II disegno della firmitas. Napoli: la Scuola di Pitagora.

Giordano Paolo (20 I 6). Il disegno della utilitas. Napoli: la Scuola di Pitagora.

Gros Pierre (1997). Vitruvio De architectura. Torino: Einaudi.

Forster K.W. (1984). Thomas Jefferson (1734- 1826). In Beltramini Guido, Burns Howard (a cura di). Palladio. Venezia: Marsilio Editore.

Pistis Eleonora (20 I I). Chiswick House \& Gardens 17I5-20 I0. In Casabella n. 797, p. 43.

Quaroni Ludovico (200 I). Progettare un edificio. Milano: Kappa.

Wittkower Rudolf (1984). Palladio e il palladianesimo. Torino: Einaudi.

Autore

Paolo Giordano, Università della Campania “Luigi Vanvitelli”, paolo.giordano@unicampania.it

Per citare questo capitolo: Giordano Paolo (2020). Connessioni_ il disegno della casa a pianta quadrata dal Rinascimento alla Contemporaneità/ Connections the drawing of the square-plan house from the Renaissance to Contemporaneity. In Arena A., Arena M., Brandolino R.G., Colistra D., Ginex G., Mediati D., Nucifora S., Raffa P. (a cura di). Connettere. Un disegno per annodare e tessere. Atti del $42^{\circ}$ Convegno Internazionale dei Docenti delle Discipline della Rappresentazione/Connecting. Drawing for weaving relationships. Proceedings of the 42th International Conference of Representation Disciplines Teachers. Milano: FrancoAngeli, pp. 51 I-528. 


\title{
Connections_the Drawing of the Square-Plan House from the Renaissance to Contemporaneity
}

\author{
Paolo Giordano
}

\section{Abstract}

The drawing of beauty expressed by Andrea Palladio's work represents the highest synthesis of Renaissance figurative culture precisely because of that summarizing ability matured following the study of Vitruvian precepts as well as the graphic and theoretical reflections present in the treatises of 15th and 16th century architects and intellectuals such as Leon Battista Alberti, Alvise Cornaro and Daniele Barbaro.

The iconographic model of Palladio's villa represents the best architectural emblem to illustrate the stages of a complex adventure of ideas, made up of conceptual and graphic connections, whose theme is the ideal home of man. The theme of the residential house based on a square plan is such a recurring theme in European architectural culture that even the contemporary design discipline, as the recent architectural elaboration of Alberto Campo Baeza's Rotunda House in Madrid demonstrates, confirms the theme of theoretical and realisable connections as a recurring mode of doing in architecture.

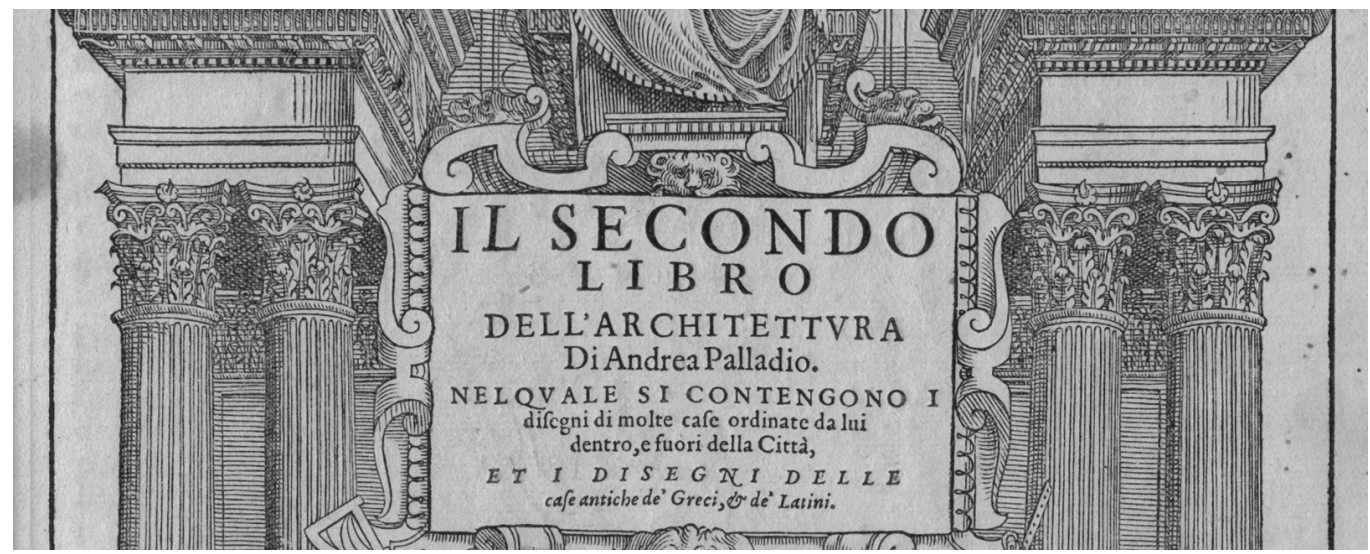




\section{Imitations of the Palladian model: the 17th century variants of the Italian-style villa}

The drawing of beauty expressed by Andrea Palladio's work, extended not only to his contribution as an excellent draughtsman but also to that of a superb treatise artist, represents the highest synthesis of Renaissance figurative culture precisely because of that summarising capacity matured following the study of Vitruvian precepts as well as that of the graphic and theoretical reflections present in the treatises of I5th and 16th century architects and intellectuals such as Leon Battista Alberti, Alvise Cornaro and Daniele Barbaro. Specifically, the La Rotonda project (fig. I) marks a clear dividing line between a before and an after within European architectural culture through the continuous reworking, between the 17th and 19th centuries, of more or less successful imitations and typological and formal connections. In this sense, the iconographic model of Palladio's villa represents the best architectural emblem to illustrate, in general, the salient features of a fundamental conceptual junction in the history of European architecture and, in particular, the stages of a complex adventure of ideas, made up of conceptual and graphic connections, having as its theme the ideal home of man. The theme of the residential house based on a square plan is such a recurring theme in European architectural culture that even the contemporary design discipline, as the recent architectural elaboration of Alberto Campo Baeza's Rotunda House in Madrid demonstrates, confirms the theme of theoretical and realisable connections as a recurring mode of doing in architecture. In this perspective, Andrea Palladio's Rotonda represents the last architectural object of Renaissance humanistic culture as well as the first typological model of an extra-urban villa for export if referred to that so-called re-propositional Mannerism that will affect the European territory, starting from the work of Vincenzo Scamozzi, in the following four centuries. As Howard Burns points out, "The most fertile export merchandise in the countries beyond the Alps was easily transported and assimilated; I Quattro Libri dell'Architettura ( 1570 ) by Andrea Palladio, in which the great architect boldly declares that he made his works available so that, in the face of the shortcomings of the ancient country houses,

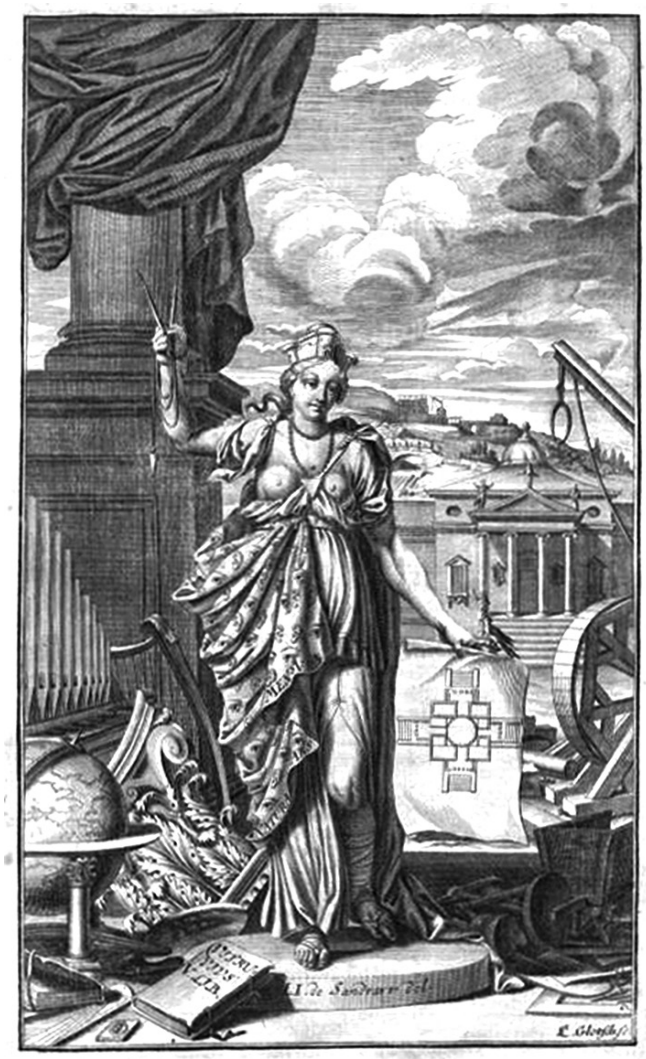


they could be an example. Palladio's book had a certain influence on the design of smaller country residences in France, but above all in England, thanks to the direct knowledge of his work by the royal architect Inigo Jones: Jones himself possessed most of Palladio's remaining drawings, which later passed from one architect to another until, in 1720-21, they were purchased by Lord Burlington, the principal director of the 17th century Palladian revival and the most creative of English Palladian architects after Jones" [Burns 20 I2, p. I I].

It is well known that the architectural model of ideal beauty represented by the Rotunda has inspired the work of many architects even outside the Italian peninsula: as well as in France - with the work of the various Antonie Le Pautre, Germani Boffrand, and Jean Nicolas Luis Durand- and in Germany - with the projects of Paul Deker, Christian Cay Lorenz- it will be in England that the greatest design tribute to Palladio's architecture and, in particular, to the beauty of Villa Capra will be developed through the construction of many residential villas, among which the Chiswick House stands out for its magnificence: an extension of an old noble residence designed by Lord Richard Boyle, third Earl of Burlington in the Middlesex countryside.

\section{The Anglo-Saxon representation of beauty: import and development of the Palladian model}

If Lord Burlington's work can be attributed to Neopalladianism, which matured in England in the 18th century, the original British Palladianism has its progenitor in the figure of Inigo Jones, a London architect who, by importing Italian Renaissance architecture across the English Channel from the beginning of the 17th century, is the only and true tutelary deity of rational Renaissance aesthetics. All this while in Italy, after the first sixteenth-century Mannerist drift, the linguistic dramatization inherent in seventeenth-century Baroque developed through the figures of Francesco Borromini and Gian Lorenzo Bernini guilty, according to Colen

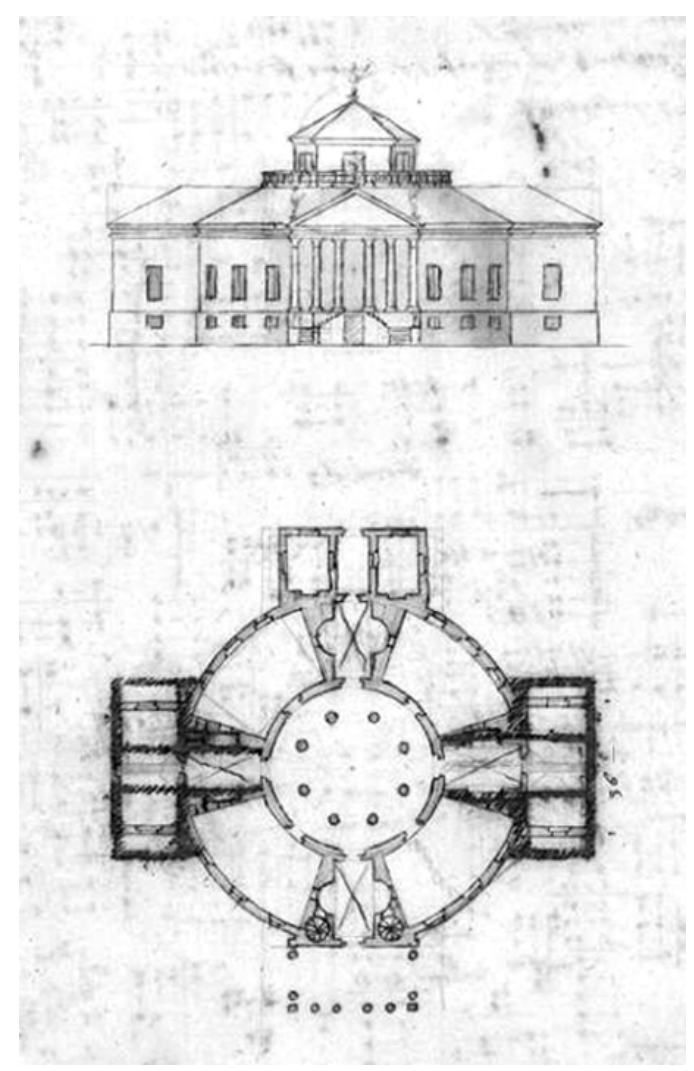


Campbell, author of Vitruvius Britannicus, of having betrayed the ideal simplicity of Antiquity in favor of capricious ornaments and incomprehensible concave-convex formalisms.

The venustas pursued by Inigo Jones is based on a rational and mathematical interpretation capable, as RudolfWittkower recalled, "of giving his buildings that global character of lucidity, balance and harmony" [Wittkower 1984, p. 92]. A character that would stiffen in the subsequent research of his students, such as, for example, in John Webb's work, which represents, in fact, the beginning of that neo-Palladianism consecrated to the imitation of the Rotonda, begun towards the end of the seventeenth century, which would lead, in the eighteenth and nineteenth centuries, both in the work of Lord Burlington and his circle of architects, and in the North American work of Thomas Jefferson. Beyond the interest for the overall work of Andrea Palladio, the exemplary architectural reference of the British neo-Palladian architects remains, in fact, Villa Capra, assiduously reinterpreted both from a typological and morphological point of view: John Webb's Single-storey house (fig. 2), although configured as a graphic exercise, represents the first attempt of the long series of architectural emulations having as object the universal beauty model designed by the Paduan architect. At the same time, in France, in a much more monumental way, Palladian-style design experimentation developed through the contribution of German Boffrand with the project of a "pavilion of delights" inserted in the park of a castle. In Boffrand's drawings for the Pavilion of Bouchefort Castle, the connection to Andrea Palladio's Rotonda is more related to the morphological aspect than to the typological one: it is, in essence, a design exercise that aspires to an aesthetic magnificence completely oversized compared to the reference model. Germani Boffrand's project, as well as that of his compatriot Antonie Le Pautre for the Maison de Plaisance, similarly to the subsequent experimentation of Herman Korb and Paul Decker (fig. 3) in Germany, did not succeed in developing an elective affinity, of a design and conceptual character, with Andrea Palladio's Rotonda in virtue of a lack of cultural background capable of nourishing a virtuous debate between architects, artists, critics and intellectuals in the countries of origin. Conversely, in England, on the basis of the intellectual and design commitment of Inigo Jo-

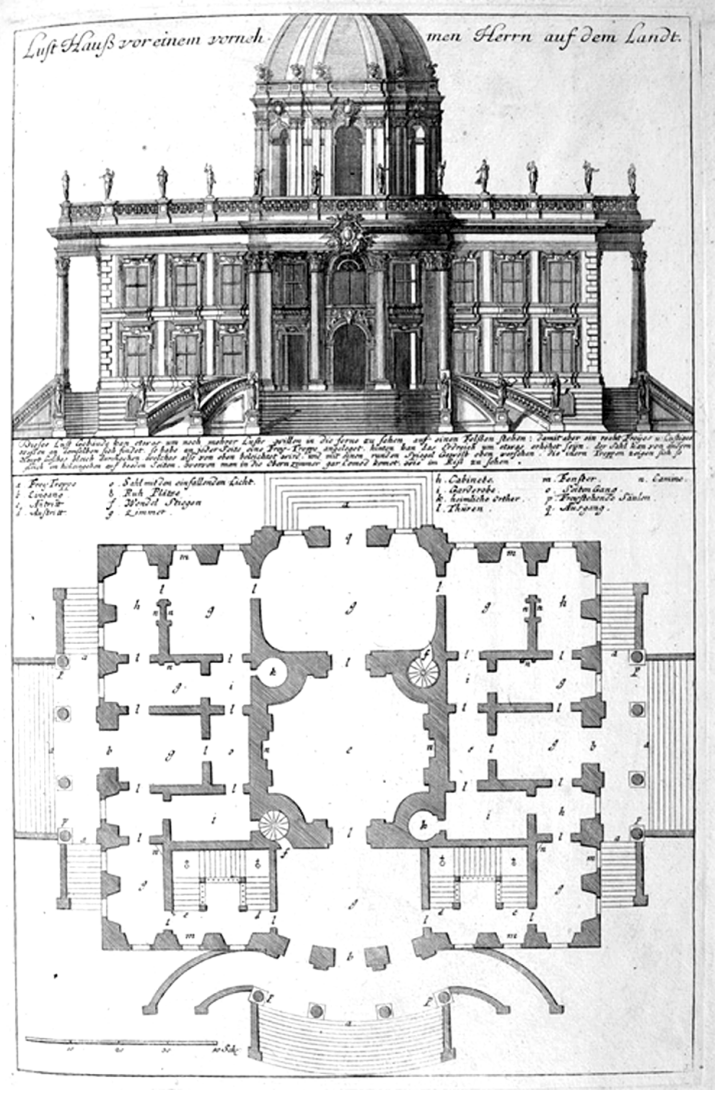



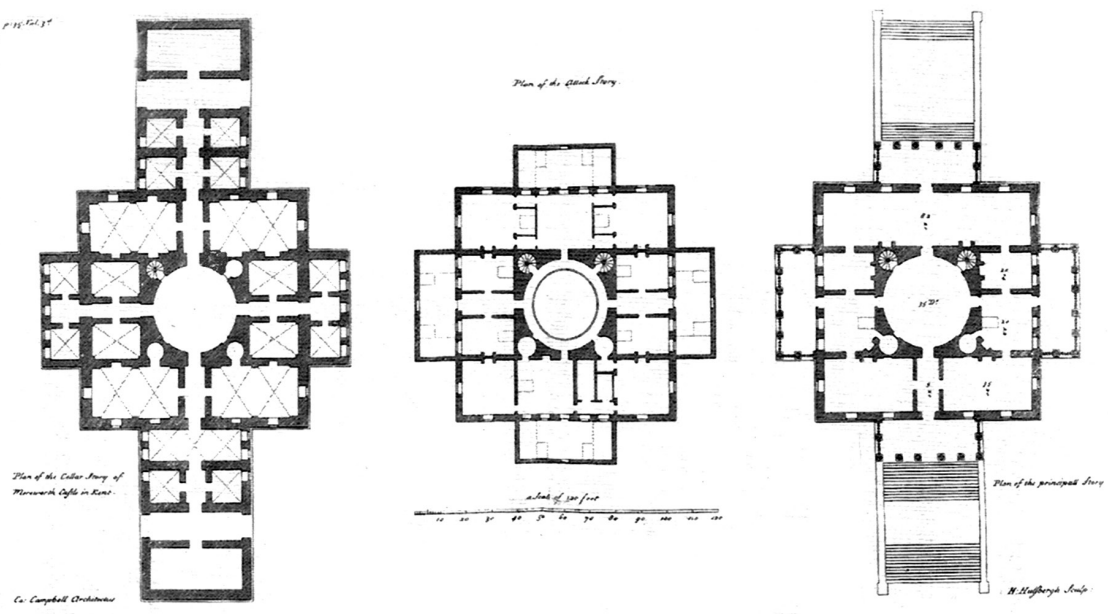

nes, the so-called English Palladianism developed: a cultural and social trend that exploded not only thanks to the contribution of the seventeenth-century master of rational English architecture but also and above all by virtue of the theoretical work of a refined British intellectual and the publicity work of an astute Venetian architect, Colen Campbell and Giacomo Leoni, authors, the former of Vitruvius Britannicus and the latter of The architecture of Palladio: in four books. Two publications, published between 17/5 and 1720, which were to act as the driving force behind the emerging neo-Palladian taste better known as "Palladian Taste". A taste that took shape in Colin Campbell's work realized in the countryside of Kent, between 1722 and 1724, (fig. 4) or Mereworth Castle.

It is an architectural work that differs little from its original architectural model, as pointed out by the designer himself, through minimal differences visible both outside and inside where the generous extension of the covered surface allows the deployment of a greater variety of shapes and sizes in the design of the rooms. A typological differentiation that can be found above all in the circular design, instead of triangular, of the rooms and staircases located around the main space, at double height, of the central hall that is more illuminated by an oculus opening onto the dome, in a variant of the project also painted by Antonio Vicentini and Francesco Zuccarelli (fig. 5). A year after the realization of Colen Campbell, in 1725, follows the homage of Lord Burlington to the Rotonda. It is, specifically, an archi-

Mareworth Castle.

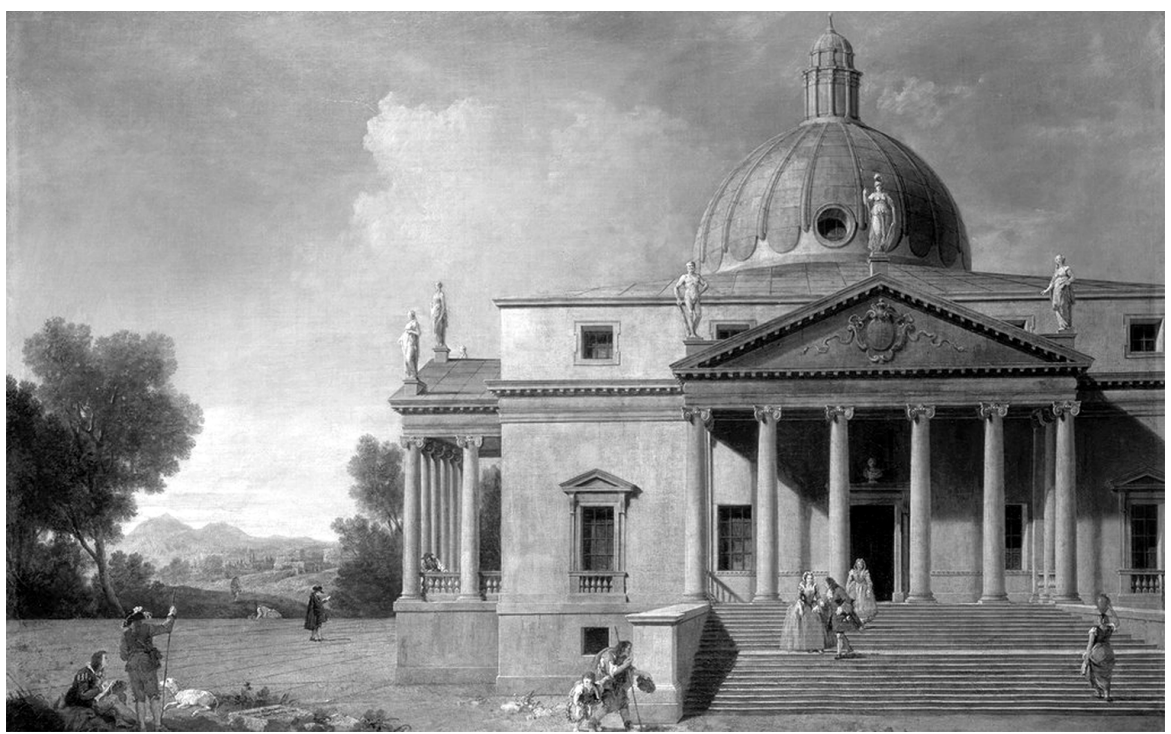


Fig. 6. Richard Boyle (Lord Burlington), elevation of the main facade of Chiswick House in London, London, Library Drawings and Archives Collection, RIBA.
Fig. 7.Thomas Jefferson, drawing for the

competition for the

President's House,

National Archives of

Maryland State, K. 126.

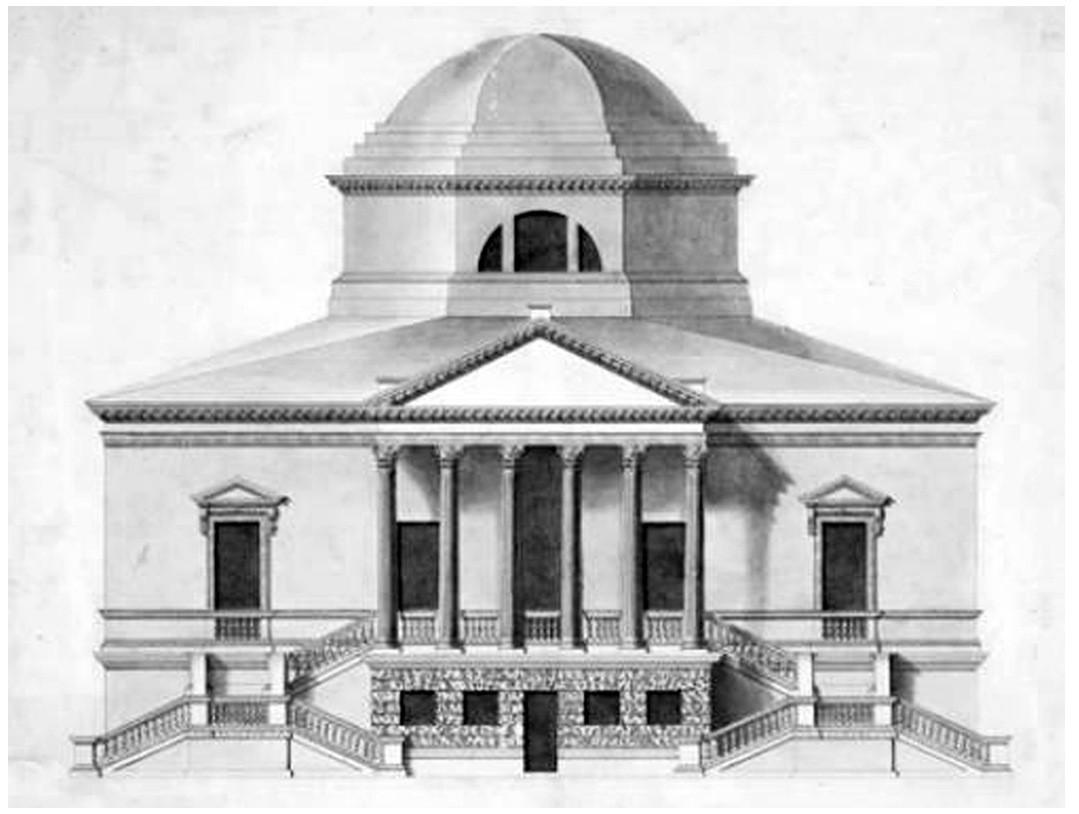

tectural homage filtered, apparently, through the lesson of Inigo Jones, his compatriot and previous admirer of Andrea Palladio: the Chiswick House, located in a dense vegetation park (fig. 6), represents the main example of British neo-Palladianism which, through the sculptures of the master from Vicenza and the London by adoption placed on the basement ends of the building, openly declares the two main sources of inspiration and, in relation to them, the self-referential elective affinity.

The Chiswick House is the representation of an imperfect neo-Palladianism, or rather of a style based on the re-proposal of linguistic elements drawn both from the teachings of Antiquity, through Vitruvius' rereading, and from the architectural solutions inherited from the Renaissance and post-Renaissance graphic testimonies of Palladio, Scamozzi and Inigo Jones. The Chiswick House represents a pale attempt to re-propose Palladio's architectural perfection which does not justify the recurrent definition of the house in the Middlesex as a "manifesto of a Palladian perfection" [Pistis 20I I, p. 43].

At the same time in France, through the design work of Gabriel-Pierre-Martin Dumont, there is a further morphological downgrading of the original work, even though it is substantially confirmed by a typological order: the design for a belvedere that the Italians call

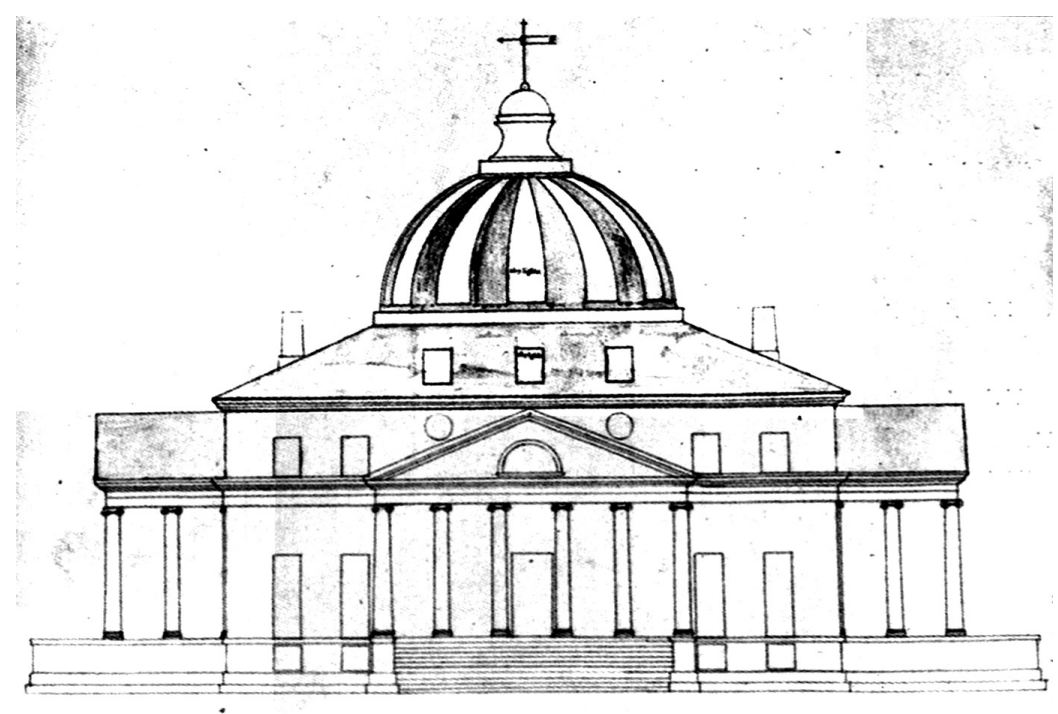


a casino proposes, in fact, the elimination of the classic hemispherical dome opting for a contradictory quadrangular sloping pitched roof set on a central hall with double height, however, still circular. To find a new hymn to beauty, consistent with Palladio's assumptions, it is necessary to shift the attention to the contemporary North American architectural production.

Thomas Jefferson's 1769 project for Monticello's house in Charlottesville and, later, the competition for the President's House (fig. 7) in the State of Maryland, in 1792, represent a true rebirth of Palladio's venustas in a new geographical context compared to that of the old European continent. The latter can be found in the drawing of the prospectus for the House of the President. A drawing not very different from the engraving illustrating the facade of Villa Rotonda in Vicenza in the English translation of Quattro libri dell'Architettura edited by Giacomo Leoni (fig. 8) and owned, together with the Rules for Drawing the several Parts of Architecture published by James Gibbs in 1732, by Thomas Jefferson himself [Forster 1984, p. 398].

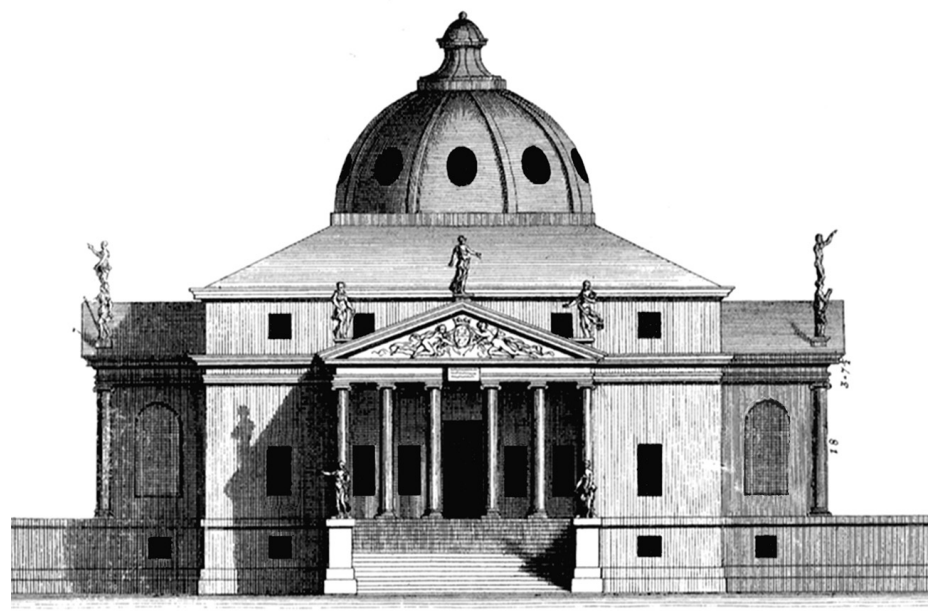

The European spread of the Palladian model between the 18th and 19th centuries: Germany and France

The utilitarian enlightenment of the second half of the eighteenth century prevented the Palladian ideal from developing and proliferating in Europe, just as the imperfect neo-Palladianism of Anglo-Saxon origin had managed to do during the seventeenth and eighteenth centuries in the suburban territories of the British island. Various residential types with a central scheme were designed and built trying, in vain, to reach that ideal beauty held by the Palladian model. Many architectural pastiches will reaffirm, through the imperfection of their own type-morphological and linguistic characteristics, the distance from the beauty expressed by Villa Capra. This is the case, for example, of the villa in the garden of Christian Cay Lorenz or the neo-decò country house of Wilhelm Gottlieb Becker as well as that of Mathias Fortunat Koller: single-residential buildings united by strong emulative tensions, equal only to their ampollary lack of architectural sobriety, with respect to Palladio's Rotonda.

Only between the end of the eighteenth and the beginning of the nineteenth century through the project of the Maison a neuf (fig. 9) by Jean Nicolas-Louis Durand- will it be possible to admire design exercises capable of restoring, outside the temptation of the mimetic re-proposal of the original model, that sense of architectural dignity to the attempt to reason on the teaching of architectural perfection, therefore of beauty, emanating from Andrea Palladio's Rotonda. 
Fig. 9. Jean Nicolas-Louis Durand, plan, elevation, sections, of the Maison a neuf cases, from Précis des leçons darchitecture, partie, Pl.2.

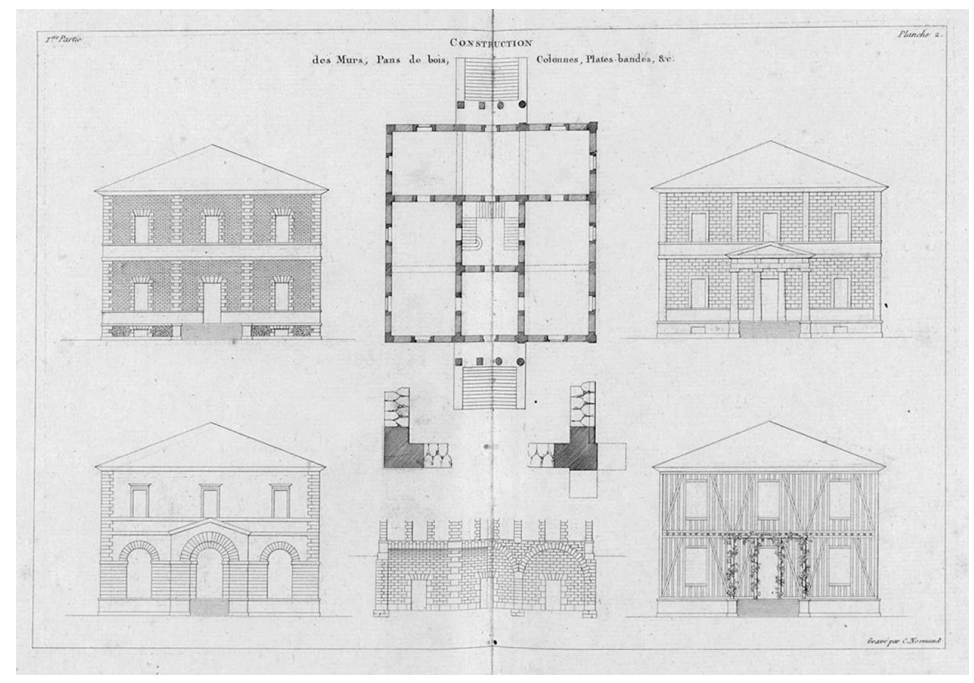

The sobriety that can be found in Jean Nicolas-Louis Durand's project for the Maison a neuf cases, published in his Precis des leçons d'architecture in Paris in 1802, is the best affirmation of the possible theoretical and design connections that architecture can support in reference to a precise, archetypal idea contained in a universal model such as Andrea Palladio's Rotonda. A model that, thanks to its theoretical and graphic connections, is able to offer answers also to our contemporaneity as it is evident from the reflections of Alberto Campo Baeza for his recent work entitled Rotonda House (fig. I0): "Building a house on top of a hill, like Palladio himself, is the dream of every architect. We are planning to build a house on the outskirts of Madrid, in a place which, despite the surrounding architecture, bears a certain resemblance to the position of some of Palladio's villas. And we are trying to learn some lessons from the master. On top of a hill where the view is more beautiful the higher you climb. And when we reach the highest point allowed by the regulations, those views are extraordinary: the sierra of Madrid, the Guadarrama, and the western edge of the city with its four towers. We propose a square plan of $|2 x| 2 \mathrm{~m}$, divided into nine equal quadrants of $4 \times 4 \mathrm{~m}$. A very flexible plan where anything is possible. The functional areas are located in the most convenient points, in the Palladian style [...] When Mies van der Rohe visits the house, he will send a WhatsApp to his friend Palladio to visit him. And Palladio will reply that he would have liked to have the means to do it like this: Mies will say that some of this went through his mind when he designed his 50x50 house" [Campo Baeza 2000].

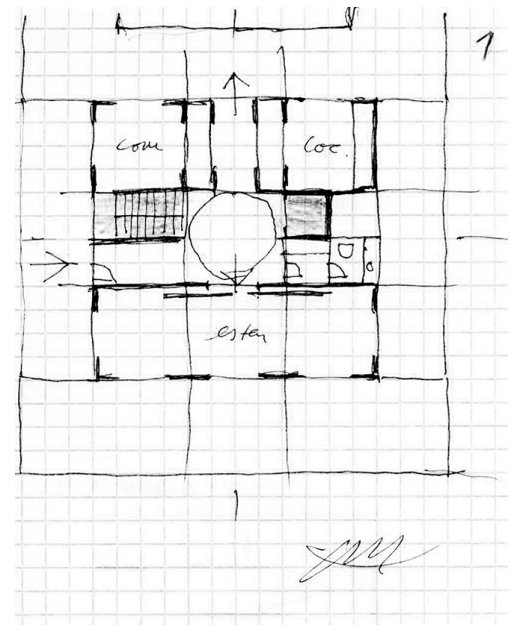




\section{References}

Burns Howard (20I2). La villa italiana del Rinascimento. Costabbisara (VI): Angelo Colla Editore.

Chiodo Simona (20 I I). Estetica dell'Architettura. Roma: Carocci Editore.

De Fusco Renato (2004). II codice di architettura. Antologia di Trattatisti. Napoli: Liguori editore.

Geymonat Ludovico (1997). Storia del pensiero filosofico e scientifico. Milano: Garzanti.

Giordano Paolo (20I5). II disegno della firmitas. Napoli: la Scuola di Pitagora.

Giordano Paolo (20 I 6). Il disegno della utilitas. Napoli: la Scuola di Pitagora.

Gros Pierre (1997). Vitruvio De architectura.Torino: Einaudi.

Forster K.W. (1984). Thomas Jefferson (1734- 1826). In Beltramini Guido, Burns Howard (a cura di). Palladio. Venezia: Marsilio Editore.

Pistis Eleonora (20 I I). Chiswick House \& Gardens 17I5-20 I0. In Casabella n. 797, p. 43

Quaroni Ludovico (200 I). Progettare un edificio. Milano: Kappa.

Wittkower Rudolf (1984). Palladio e il palladianesimo. Torino: Einaudi.

Author

Paolo Giordano, Università della Campania “Luigi Vanvitelli", paolo.giordano@unicampania.it

To cite this chapter. Giordano Paolo (2020). Connessioni_ il disegno della casa a pianta quadrata dal Rinascimento alla Contemporaneità/Connections the drawing of the square-plan house from the Renaissance to Contemporaneity. In Arena A., Arena M., Brandolino R. G., Colistra D., Ginex G., Mediati D., Nucifora S., Raffa P. (a cura di). Connettere. Un disegno per annodare e tessere. Atti del $42^{\circ}$ Convegno Internazionale dei Docenti delle
Discipline della Rappresentazione/Connecting. Drawing for weaving relationships. Proceedings of the 42 th International Conference of Representation Discipline della Rappresentazione/Connecting. Drawing for
Disciplines Teachers. Milano: FrancoAngeli, pp. 5 । I-528. 